\title{
The Effect of Integrating Mobile Technology in Micro Finance Institutions. Case of Small and Micro-Enterprise Program (SMEP) In Kisumu County
}

\author{
${ }^{1}$ Kwama Leonard Ogweno, ${ }^{2}$ Obare Erick Oteyo, ${ }^{3}$ Ondiek Alfred Collins \\ ${ }^{1}$ Maseno University, School of Computing and Informatics, Department of Information Technology. Private \\ Bag, Maseno, Kenya; \\ ${ }^{2}$ KCA University, Faculty of Computing and Information Management. P.O Box 3207-40100, Kisumu, Kenya:
}

\begin{abstract}
Executive Summary: Recognizing the potential that M-banking holds in strengthening the socioeconomic position of those currently lacking access to banking, especially the rural poor, Safaricom in Kenya and the two leading mobile operators in the Philippines (SMART2 and GLOBE) have both become facilitators of banking through the mobiles. Many studies carried out in the banking industry from the third world countries have found that M-banking is the best for an improved banking service in developing countries(Lyman et al, 2008; Guriting and Ndubisi 2006; Cheney 2008). However, little studies have been done on impact of integrating mobile technology banking on the performance of Micro Finance Institutions (MFIs) which therefore forms the basis of this study. The purpose of the study was to assess the impact of integrating mobile technology services on the performance of Micro Finance Institution, a case study of Small and Micro Enterprise Program (SMEP) in Kisumu County. This study was guided by the following study objectives; to find out the effect of information as a component of mobile banking service on the performance of Small and Micro Enterprise Program (SMEP), to investigate the effect of $m$ - banking transaction as a component of mobile banking service on the performance of Small and Micro Enterprise Program (SMEP), and to explore the effect of orchestrated function of mobile banking service on the performance of Small and Micro Enterprise Program (SMEP).This study utilized descriptive survey design. A sample size of 66 respondents was used for the study. The data was obtained through the use of questionnaire which was administered through the help of the research assistants. Data analysis employed descriptive statistics, where Statistical Package for Social Sciences (SPSS) software was used to generate measures of frequencies. This study will benefit to greater extent the banking industry, the government, other economic stakeholders and the general public.
\end{abstract}

Key words: Mobile technology, Banking, Small and Micro Enterprise Program

\section{Background to the study}

\section{Introduction}

According to a recent Consultative Group to Assist the Poor (CGAP) survey which involved 152 MFIs, it was realized that Sub-Saharan Africa, South Asia and East Asia and the Pacific have the greatest number of MFIs using manual systems and spreadsheets (roughly 20 percent). Banks and Rural Banks reported to mostly using manual systems (roughly 10 percent). The remaining systems are off-the-shelf or custom built. This lack of industry standardization can potentially increase costs for MFIs (CGAP, 2009). According to Mark Pickens (2009) it seems like every week there's a new market study that comes out about mobile banking - but few of those (if any) focus exclusively on the opportunity to be found in serving poor, unbanked people in developing countries (Pickens, 2009).

One of the recently emerging technologies in the microfinance industry is the use of mobile phone technology for both banking and remittance. According to a research firm Gartner Inc., Mobile payment users will reach 74.4 million in 2009, an increase of 70 percent over the 43 million users in 2008. In 2012, that number should exceed 190 million users. Once the 2012 level is reached, Gartner said more than 3 percent of all mobile-device users was making mobile payments, at which point the practice will have become mainstream (Hamblen, 2009). The UN projects that there will be four billion mobile phone connections globally, with millions of air-time resellers and retail agents in developing countries making it possible to distribute financial services at far lower cost than through traditional channels (Rosenberg 2008). By the year 2012 CGAP and GSMA estimate that there will be 1.7 billion people with a mobile phone but not a bank account and as many as 364 million unbanked people could be reached by agent-networked banking through mobile phones (Rosenberg, 2009).

For most customers mobile banking presents a delicate balance between a conceptually powerful opportunity being able to transact anytime, anywhere and practical challenges finicky menub sequences on a small screen and tiny buttons (Kumar, 2008). Ivatury and Mas (2008) predicted that poor people are more likely 
to use mobile phones to undertake financial transactions than rich people. People in less developed countries have very few options, if any, for transferring money and accessing banking services. Further, in the developing world there is less formal banking infrastructure few bank branches, automated teller machines and low internet penetration.

Recognizing the potential that M-banking holds in strengthening the socioeconomic position of those currently lacking access to banking, especially the rural poor, Safaricom in Kenya and the two leading mobile operators in the Philippines (SMART2 and GLOBE) have both become facilitators of banking through the mobiles. Their respective services, M-PESA, SMART Money and G-Cash, enable users to send and receive money, pay bills and taxes, and purchase items in shops through simple SMS-based services.

In order to improve efficiency in the delivery of microfinance services, Kenya's leading mobile operator, Safaricom Limited, has collaborated with several microfinance institutions including the Small and Micro-Enterprise Program (SMEP) to offer financial services through mobile technology. In Kenya, where the banking system is not well distributed, especially in the rural areas, such a system has proved a success in utilizing the existing large network of mobile phone users, airtime dealers, shops, and kiosks, where cash can be collected and paid in. However, despite the fact that mobile phones are ingenious devices, one thing they cannot do by themselves is to convert cash into electronic value or dispense cash. Mobile phones can only be used to transfer or transform value electronically. A mobile banking platform therefore needs to be supported with cash conversion platform, whether full-blown bank branches, ATM terminals or third party agent (Kumar, 2008). This means that any financial institution wishing to embrace the mobile banking technology, to increase outreach of its services to new geographical locations, will need to set up cash in/cash-out network in the same geographical region.

\section{Statement Of The Problem}

Kenya has one of the most dynamic financial sectors in Africa with over 40 banks, over 1500 SACCOs, microfinance institutions, insurance companies, and the Nairobi stock exchange, which is one of the largest in Africa and which is ranked fourth in terms of trading volume. However, despite the wide range and the high number of financial institutions, access to financial services has been limited to urban and peri-urban areas of the country. A recent Financial Access study undertaken jointly by the Central Bank of Kenya and Financial Sector Deepening, identified that only 22.6 percent of the total population aged 18 years an above have access to formal financial services i.e. from the banks, Post Bank and insurance products.

Technology is consistently cited as one of the greatest challenges faced by microfinance institutions (MFIs) around the world. It is widely recognized that technology is invaluable for improving efficiency, accuracy, increasing outreach and reducing costs. However, many MFIs lack sufficient funds and to invest in suitable backend technologies, such as mobile banking technology and Internet remain scarce. Still others sink funds into poor technology investments, or simply choose not to invest, limiting their ability to grow and compete (Rosenberg, 2009). While it cannot be argued that M-banking is the best for an improved banking service in developing countries, it is, however, certain that traditional banking service alone may not result in any significant improvement in providing the un-banked community with access to financial services. The speed and efficiency with which money can be transferred and monitored, through such mobile platforms, is likely to be far greater and higher as compared to a cash-based system. As a consequent, this study aims to assess the effect of mobile banking on the performance of Microfinance Institutions.

\section{Literature Review}

\section{Informative role of mobile banking services in Micro Finance Institutions}

Financial institutions have extensive knowledge of financial models and a good reach worldwide. Mobile Banking provides them with an opportunity to further enhance their customer reach by migrating customers upward in the use of mobile technology move the "un-banked" community toward the "banked" status. According to Amin, (2007), Mobile Network Operators (MNOs) have a unique advantageous position, as they are the first-point of contact with the customers. They also tap the growing subscriber base with new offerings providing consumers a strong value proposition. Thus, MNOs should be looking at M-banking as an important source of revenue (Cheney, 2008).

As the core competence of the MNOs lies in delivering mobility solutions to their customers, it is prudent for them to partner with a financial institution in order to gain access to credit facilities, credit payment management and other financial services. However, with banks not being able to reach the unbanked, who represent half of the world's population, with their traditional distribution channels of braches and ATM's, mobile phone operators are taking full advantage of that gap and are penetrating to the unserved market (Hayat 2009). With more than 4 billion mobile subscriptions in the world today; according to Wireless Intelligence this deep reach of mobile is a potential launch pad for a considerable commercial opportunity of up to US $\$ 7.8$ billion in direct and indirect revenues by 2012 (Pickens, 2009). The success of mobile payment and mobile 
banking systems, such as M-PESA in Kenya, has exceeded expectations, with greater numbers of formal financial sector actors taking notice.

Cash transactions, account opening and other transactions can be conducted online. This makes it easy to subscribe and accounts for the high customer concurrence of $91 \%$. Ultimately transformational banking boosts access to formal finance particularly, in rural areas where many poor people live. Of the total 876 branches operated by financial institutions in Kenya 314 are in Nairobi. M-banking has opened a different access door for the unbanked. According to the Central Bank of Kenya (CBK), M-PESA Kenya's leading mobile payment system offered by Safaricom may have already made an impact on the formal financial sector, given the increase in formal bank accounts during the period M-PESA has been operational. At the end of 2005 , there were 2.6 million formal bank accounts, but by the end of 2008 that number had increased almost 150 percent to 6.4 million accounts. There are over 7,000 M-PESA agents2-substantially more points of service than the combined number of bank branches (887) and automatic teller machines $(1,435) 3$ in the country serving 6 million customers or $15.3 \%$ of Kenya's population of 39 million4. The monthly value of person-toperson money transfers as of the end of February 2009 was KES 14.5 billion (USD 190.3 million5), and the cumulative value of these money transfers since launch in March 2007 of the service is KES 118 billion (USD 1.5 billion). Safaricom's CFO asserted in a June 2008 interview that Safaricom is the biggest generator of cash in Kenya, with the exception of the government6 (Hayat 2009). The study further identified the fact that 32.7 percent are financially excluded, though it was a decrease from 38.4 percent in 2006.

The study further notes that almost half (47.5percent) of all Kenyan adults own a mobile phone (up from 26.9 percent in 2006), with the rate of ownership rising to 72.8 percent in urban areas (up from 52.3 percent in 2006) and 80.4 percent in Nairobi (up from 63 percent in 2006). (Kenya, 2009) Further, 52 percent received money in 2009 compared to 16.5 percent in 2006. However, international remittances are still low, but 4.3 percent claimed to have received money in 2009, up from 2.8 percent in 2006.The most popular means of money transfer being M-PESA, now used by 39.9 percent of all adults in Kenya. Twenty six percent of all MPESA users also save money on their phones. One in six users, store value in their phone for use while travelling; M-PESA is perceived as the least risky by 26.2 percent of respondents, least expensive (31.7 percent), fastest (64.3 percent), easiest to get (47.8 percent) means of money transfer (Kenya, 2009)

\section{Mobile banking transactions and its effects on the performance of Micro Finance Institutions}

Branchless banking is the use of technology, such as mobile phones and bank cards, for the conduct of financial transactions electronically and remotely. The use of third party outlets as agents for example, retail shops, supermarkets and even gas stations for provision of financial services allows customers access to financial services without going to bank branches which ordinarily are located far away from the customers. In addition to transactional services, branchless banking provides basic cash deposit and withdrawal services (Ivatury \& Mas, 2008).

Ivatura and Mas (2008) further notes that branchless banking has great potential to extend the distribution of financial services to the poor people who are not reached by traditional bank branch networks; it lowers the cost of delivery, including costs both to banks of building and maintaining a delivery channel and to customers of accessing services (e.g.travel or queuing times) (Ivatury and Mas, 2008).

According to Amin (2007), mobile banking or M-Banking also refers to the provisioning and availability of banking and financial services through mobile technology and the scope of services offered may include facilities to conduct bank and stock market transactions, as well as enabling users to access customized information. Mobile Remittances, Micro-finance and Micro-payments services are likely to fuel the growth of M-banking in the developing countries especially amongst the un-banked segment (Amin, 2007). However, the biggest question to ask is; what role can mobile telecommunications play in providing banking services? One view is that mobile technology is just another, although highly innovative, access channel; an alternative is that mobile telecommunications networks are becoming the front office for financial services leaving the existing banks as providers of back office functions. But there is also another view which seeks to define the competitive advantages of the banking and mobile finance business models and then explore the ways in which these could give rise to new market structures within which the existing portfolio of financial services (savings, credits and transactions) can be unbundled (Williams \& Torma, 2007).

According to Williams and Torma (2007), mobile transactions can simultaneously enhance the outreach of financial services, reduce information asymmetries and provide relatively low cost informational and transactional financial products. It therefore has the potential to transform the access to finance for a significant number of people. It brings closer to reality the aspiration to provide mass access to finance to all countries and income groups (Williams \& Torma, 2007, p 18). Microfinance was initially developed to provide access of credit services to the low-income households and also as a way to build and expand their financial resources. From a small experiment of delivery of credit by Prof. Mahammad Yunus the founder and Chairman of Grameen Bank, microfinance has grown dramatically not only in the provision of credit but also a wide range 
of financial services ranging from savings to insurance for the low income people. However, despite the exponential growth experienced in the last couple of years, as well as the growing success in reaching the unbanked, many low income households still continue to lack access to formal or semi-formal financial services (Kohen, Hopkins, \& Lee, 2008).

In the recent past, microfinance programs have become one of the more promising ways to use scarce development funds to achieve the objectives of poverty alleviation. Traditionally, banks and lending institutions would not lend money to low-income individuals due to various reasons, which include the lack of information about clients, the lack of acceptable collateral, and the high transaction cost of processing small loans (Guriting and Ndubisi 2006).

While countries such as the Philippines and Vietnam rely on a large microenterprise sector to fuel the economy, not many financial institutions, including rural banks, until recently, were enthusiastic and well equipped to service their needs. However, currently, the scenario is changing and there has been a growing market in the developing countries for lending services provided mostly by non-governmental organizations. The rapid growth in the recent years coupled with commercialization of microfinance services has led to the emergence of more innovative and creative delivery channels of financial services to the rural areas. E-business has been continuously growing as a new industry during the last decade (Van 2001).

The banking industry has been leading this trend in recent years, and now all banking transactions completing through internet applications is sometimes called e-banking (Smith, 2006; Hwang et al., 2007; Shin, 2008). E banking has revolutionized the way business is transacted by globalizing the business enterprise.

E-banking technologies have proliferated in recent years, and the availability of a wide range of products has led to increasing adoption among consumers. These technologies include direct deposit, computer banking, stored value cards, and debit cards (Servon and Kaestner, 2008). Consumers are attracted to these technologies because of convenience, increasing ease of use, and in some instances cost savings (Anguelov et al., 2004). E-banking has been viewed as an upgrading from previous electronic delivery systems to open new business opportunities for the banking industry (Ebling, 2001). The Cellular telephone (commonly "mobile phone" or "cell phone" or "hand phone") is a long-range, portable electronic device used for mobile communication.

For the past two decades, the banking sector has chosen a new service channel based on the progress of information technology internet to respond to the changes in customer preferences and needs, increasing competition from non-banks, changes in demographic and social trends, and government deregulations of the financial service sector (Byers and Lederer, 2001). In the search for sustainable competitive advantages in the technological financial service industry, banks have acknowledged the value to differentiate themselves from other financial institutions through new service distribution channels (Daniel, 1999).

In addition, customer's transaction and communication abilities have been improved by the developments of information technology. Information technology enabled electronic channels to perform many banking functions that would traditionally be carried out over the counter (Giannakoudi, 1999). The rise of electronic payments media such as debit and credit cards has caused the value of paid in the USA to fall to from about $\$ 49$ billion in 1995 to about $\$ 42$ billion in 2002 (Gerdes and Walton, 2002).

The use of paper cheques has been supplemented step-by-step with e-cheques (i.e., electronic images) allowing banks to have more storage capacity, reduce costs, and improve Furthermore customer services (Rose and Hudgins, 2005).

A more recent e-banking development is wireless internet applications of banking sometimes called mbanking (Rao and Prathima, 2003). With the combination of two most recent technological advancements internet and mobile phone, a new service (mobile data service) is thus enabled and the first such wireless internet commercial transaction is performed by the banking industry (Barnes and Corbitt, 2003). It is believed that m-banking will provide another new channel for banking services, especially for certain remote areas where online internet is still unavailable. Strategic implications and customer perception of m-banking services are explored (Lyman et al, 2008) with a focus on the consumer value creation and a better understanding about the customer-perceived value of m-banking services. For instance, mobile internet service has been quite popular in Japan (over 60 million users in 2003) especially for those young and single (i.e., unmarried) consumers (Scornavacca and Barnes, 2004).

Due to the widespread use of computer technologies in almost all aspects of life, organizations that are connected to the Internet started extending their services to their customers to include new applications and services that satisfy their customers' desires to make better businesses. One of these emerging applications is mobile banking. The term mobile banking (or m-banking) describes the banking services that the user can perform via a mobile device ubiquitously at anytime and from anywhere. In order for users to access their accounts, they need a mobile device and network connectivity. Therefore, sitting in front of a computer is not a requirement anymore; accessing accounts can occur while users are waiting their turn at the dentist clinic or relaxing at the beach (Al-Akhras and Qwasmi, 2011). Sylvie and Xiaoyan investigate the market status for 
online/mobile banking in China. With the recent and forecasted high growth of Chinese electronic banking, it has the potential to develop into a world-scale internet economy and requires examination.

The results showed Chinese online and mobile bank users were predominantly males, not necessarily young and highly educated, in contrast with the electronic bank users in the West.

According to Comninos et al (2006), 'online banking is the best thing to happen to personal finance management since the invention of the paper statement. In many countries, half or more of online users routinely visit their bank to check account activities, verify deposits, and just see if everything is in order'. According to a report by Mintel International Group Ltd (June 1, 2006), the forces driving the growth of the Internet-increased broadband access, new innovations that provide a secure environment, and the coming-of-age of more techsavvy people-will combine to propel online banking as well. Mintel expects that online banking will continue to grow and become more profitable for financial institutions, particularly as the Internet matures and subsequent generations become more technologically literate. Factors impacting online banking include the trend within the industry and the socioeconomic forces behind changing demographics. Mobile Banking is a financial transaction conducted by logging on to a bank's website using a cell phone, such as viewing account balances, making transfers between accounts, or paying bills. This can be conducted through the internet browser on the phone, through a program downloaded from your bank, or by text-message (SMS). Mobile banking is an application of mobile computing which provides customers with the support needed to be able to bank anywhere, anytime using a mobile handheld device and a mobile service such as text messaging (SMS).

Mobile banking removes space and time limitations from banking activities such as checking account balances, or transferring money from one account to another. In recent research and studies it was found that while mobile banking and more specifically SMS-based mobile banking applications have become popular in some countries and regions, they were still not widely used.(Yu Shi:" Factors influencing the use of Mobile Banking: The case of SMS based Mobile Banking") His study identifies and investigates the factors which influence customers' decision to use a specific form of mobile banking, and specifically focuses on the evaluation of SMS-based mobile banking in the context of New Zealand. His research model includes the basic concepts of the Technology Acceptance Model (TAM), as well as some constructs derived through a focus group discussion (Ayadi, 2005).

The telecommunications industry worldwide has scrambled to bring what is available to networked computers to mobile devices (Schofield \& Kubin 2002). Presently, the use of electronic banking is considerably high and as more and more users sign up for electronic-banking, the maturity as regards remote banking (i.e. banking outside the banking hall) is on the increase.

With electronic banking, users can now conveniently carry out banking transactions, but this convenience cannot be achieved if the user does not have access to the internet, hence, in other words, the user cannot carry out a banking transaction while waiting for a bus, or perhaps while having lunch in a restaurant. With m-banking, convenience can be achieved 24hrs a day. This is because a user has access to his mobile phone all day, at all times. So, to effectively achieve a truly convenient banking mode, a truly mobile mode of banking has to be explored, hence the need for m-banking (Andrew, 2009)

According to Rasheda Sultana, across the developing countries, millions of people rely on informal economic activity and local level networks to earn their living. Most of these populations are from bottom of pyramid and they don't have access to basic financial services/banks as access to them is costly and very limited. With over 4 billion mobile cellular subscriptions worldwide, mobile network has the ability to immediately offer mobile banking to $61 \%$ of the world population (Sultana, 2009).

With the improvement of mobile technologies and devices, banking users are able to conduct banking services at anyplace and at anytime. The reason to understand what factors contribute to users' intention to use mobile banking is important issue of research. The researcher's purpose is to examine and validate determinants of users' intention to mobile banking. He used a structural equation modeling (SEM) to test the causalities in the proposed model. The results indicated strong support for the validity of proposed model with $72.2 \%$ of the variance in behavioral intention to mobile banking (Morna et al. 2003).

Mobile banking is growing at a remarkable speed around the world. In the process it is creating considerable uncertainty about the appropriate regulatory response to this newly emerging service. Researcher sets out a framework for considering the design of regulation of mobile banking. Since it lies at the interface between financial services and telecoms, mobile banking also raises competition policy and interoperability issues that are discussed in his paper. Finally, by unbundling payments services into its component parts, mobile banking provides important lessons for the design of financial regulation more generally in developed as well as developing economies (Hayat 2009).

The use of mobile phones in order to effectuate banking transactions is bound to increase in a significant way in the near future. This growth in mobile financial services not only depends on technological advances, but also on consumer confidence in the provided services. Mobile financial services can be divided into mobile banking and mobile payment; therefore, legal certainty must be established as to what supervisory 
regime applies to the various activities involving banks and non-banks (Souranta 2003). Mobile banking activities fall within the scope of the banking business, and oversight is provided by the competent financial market authority for prudential supervision, if the definition of banking activities encompasses all relevant mobile banking activities. Furthermore, legal aspects also play a role in the evolution of mobile banking as far as the need to enhance customer trust in the offered services is concerned. Major issues arise in relation to data security and consumer protection. Moreover, the outsourcing of certain key activities to mobile operators deserves further attention, as mobile operators can, under specific circumstances, become deeply involved in mobile banking (Weber, 2010).

New electronic channels are replacing the more traditional ones. Mobile devices represent the recent development in electronic service distribution. An exploratory study was conducted on experienced electronic banking customers by using a qualitative in-depth interviewing method. The findings increase the understanding of customer-perceived value and value creation on the basis of attributes of mobile services and customerperceived disadvantages of mobile phones in electronic banking context. The findings allow practitioners to improve their services and marketing strategies and pass on information to the academics about interesting future research areas (Laukkanen, 2005).

\section{Knowledge Gap}

Mobile banking is growing at a remarkable speed around the world. It is a financial transaction conducted by logging on to a bank's website using a cell phone, such as viewing account balances, making transfers between accounts, or paying bills. Application of this technology in the banking sector has elicited several studies and research works over its ability to take the banking sector to greater heights. For instance, Andrew, (2009), studied the 'Mobile Banking in Developing Countries taking a case study of Kenya and in his findings, Mobile Banking provides the financial institutions with an opportunity to further enhance their customer reach by migrating customers upward in the use of mobile technology move the "un-banked" community especially the rural folk toward the "banked" status. Another study was also conducted by Laforet and Xiaoyan (2004) on "Consumers' attitudes towards online and mobile banking in China". According to these researchers, mobile banking is a powerful tool that can be used to deliver financial services to millions of clients who have a mobile phone but do not have a bank account due to challenges associated with accessing financial services, especially in the rural areas of a country.

\section{Conceptual Framework}

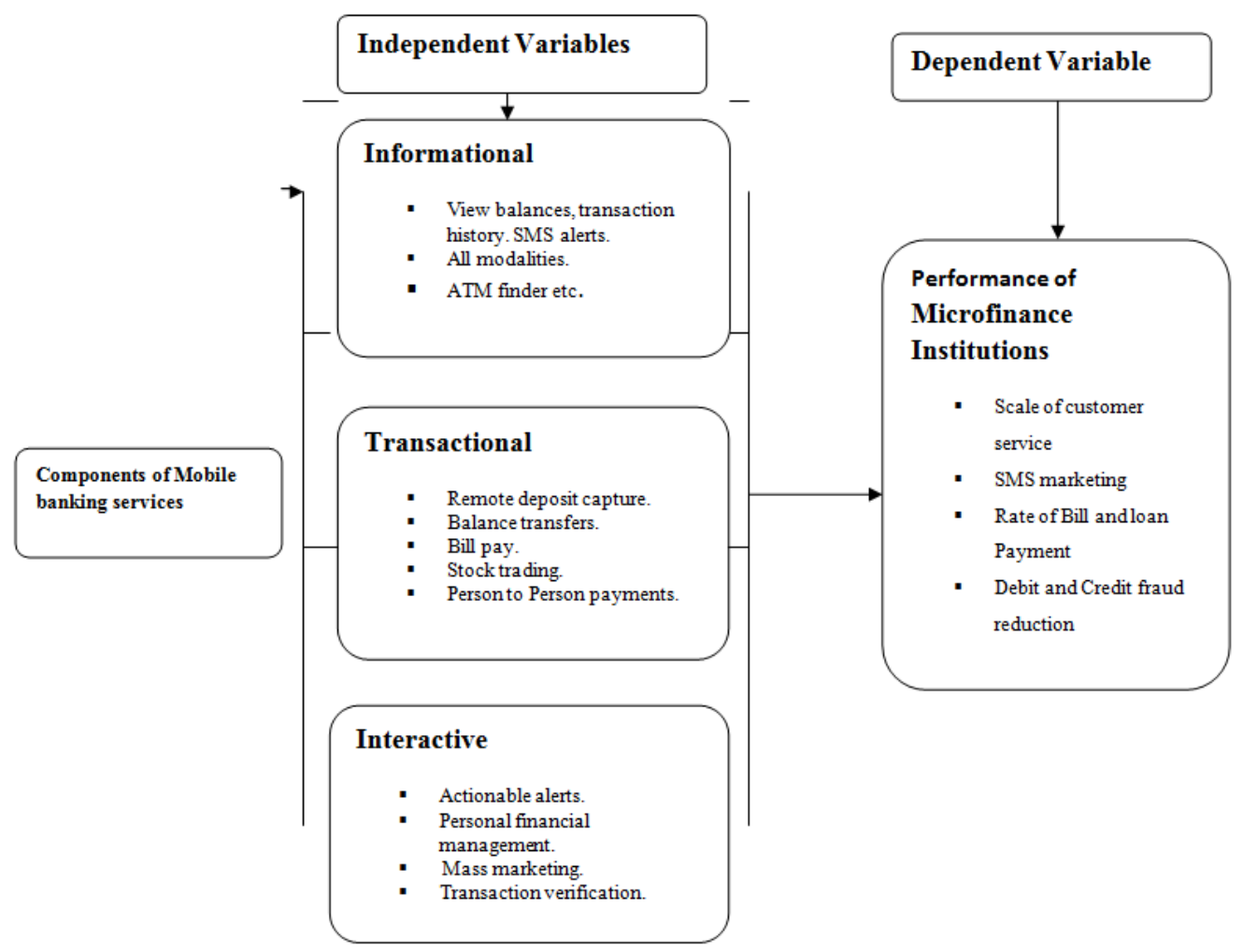

\section{Operation of the model}

According to the conceptual framework, the components or the products of the mobile banking services such as informational, transactional, interaction and orchestration, which constitute the independent variable 
affects the performance of the microfinance institutions (dependent variable) based on scale of customer service, SMS marketing, rate of bill and loan payment and debt and fraud reduction.

\section{Methodology}

\section{Research Design.}

In order to capture sufficient relevant information about assessing the effects of mobile banking on growth of a microfinance institution, a case study of SMEP in Kisumu City, descriptive design was used, this is because the design is excellent for measuring attitudes and orientation in a large population. In addition, it uses both qualitative and quantitative data in order to find a solution to the study problem. The descriptive design is simple and enables a researcher to use two or more variables to analyze a study problem. According to Babbie (2007) descriptive are used in studies that only individual as the unit of analysis and they are also flexible. In this study the units of analysis are the individuals who are the loyal customers of SMEP and have adopted mbanking services.

\section{Target Population and Sample Size}

This study targeted mobile banking users specifically the loyal customers of SMEP in of Kisumu County. Currently, the institution has a clientele base of almost 2000 with m-banking services. This is the study population and a sample frame from which the sample size will be drawn. According to Kombo and Delno (2006), a sampling frame is a list of elements from which the sample is actually drawn and closely related to the population. Therefore, it is from this sample frame that the sample size was drawn. The study also targeted 20 employees of SMEP as key informants to provide the in depth information on the study, especially when some of the information were not available with the customers.

In addition, the study used saturation method to interview all the 20 employees in Equity Bank.

\begin{tabular}{|l|l|l|l|}
\hline Target population & Total population & Sample size & Percentage \\
\hline SMEP Clients & 2000 & 322 & $16 \%$ \\
\hline Equity employees & 20 & 20 & $100 \%$ \\
\hline
\end{tabular}

\section{Response Return Rate}

\section{Findings}

This section presents response rate for varied groupings of respondents that were targeted during the study period. Quantitative primary data was obtained through issuance of questionnaires to the respondents who were the loyal clients of SMEP microfinance Institutions. This data was gathered by research assistants who directly administered the questionnaires to the study respondents. The response rate was shown using table 4.1 as illustrated below;

Table 4.1: Questionnaire Response Return Rate

\begin{tabular}{lccc}
\hline Category & Target Size & Responded & Percentage (\%) \\
\hline SMEP loyal clients & 50 & 48 & 96 \\
Non response & & 2 & 4 \\
\hline TOTAL & $\mathbf{5 0}$ & $\mathbf{5 0}$ & 100 \\
\hline \hline
\end{tabular}

\section{Source; Research data (2014)}

Out of 50 respondents targeted in this category, 48 (97\%) responses were obtained. This implies that all except two respondents targeted in this category took part and responded to the study questionnaire. This was accomplished because the study made call-backs to interviewee targeted to make certain that each and every one took part in the study as was predicted. However, only two respondents failed to respond to the questionnaire after being introduced to the study. This is in line with the Nachmias and Nachmias (2005) argument which asserts that a response rate exceeding $75 \%$ is acceptable for any academic survey study. The quantitative data analyzed, presented and discussed depends on this category of respondents.

\section{Effects of Information as a Component of Mobile Banking Service on the Performance of Microfinance Institution}

The study sought to investigate how information as a product of mobile banking affects the performance of SMEP microfinance institution. This section presents the customer's opinion on and attitude on this component of microfinance. Evaluating the customer's attitude and opinion on the contribution of information on the performance of SMEP microfinance institution was highly significant in order to highlight the effect of microfinance on the performance on the microfinance institutions. 


\section{M-banking provides prompt information services to the customers}

The study wanted to find out the opinion and attitudes of the customers regarding the speed and promptness of the information they receive from the financial intuitions through m-banking services. Table 4.2 shows the response

Table 4.2: M-banking provides prompt information services to the customers

\begin{tabular}{lcc} 
& Frequency Response & Percentage Response \\
\hline Yes & 46 & 96 \\
No & 2 & 4 \\
\hline Total & $\mathbf{4 8}$ & $\mathbf{1 0 0}$ \\
\hline \hline
\end{tabular}

Source; Research data (2014)

Of the 48 respondents interviewed, 46 (46\%) of respondents admitted that ever since the microfinance institution adopted m-banking technology, they have continued to receive the banking information promptly. However, a paltry $2(4 \%)$ could not see the relationship between adoption of mobile banking and the speed they receive the information, claiming that still the speed of conveying information has not improved.

\section{Effects of prompt information services due to m-banking on the customer base}

The study wanted to investigate whether prompt information services due to m-banking positive effects on the clientele base.

Table 4.3shows the findings

Table 4.3: Prompt delivery of banking information has increased the customer base of the microfinance intuitions

\begin{tabular}{lcc}
\hline & Frequency Response & Percentage Response \\
\hline Yes & 40 & 83 \\
No & 6 & 13 \\
I don't know & 2 & 4 \\
\hline Total & $\mathbf{4 8}$ & $\mathbf{1 0 0}$ \\
\hline \hline
\end{tabular}

Source; Research data (2014)

Of the 48 respondents interviewed, $40(83 \%)$ of respondents confirmed that ever since the microfinance institution they have witnessed the clientele growth of the microfinance institution. However, only $6(13 \%)$ did not agree with this statement, while $2(4 \%)$ could not tell whether there is a relationship between prompt delivery of banking information and the growth of the customer base.

\section{M- Banking Transactions as a Component of Mobile Banking Service On the Performance}

The study sought to examine how m-banking transactions as a product of mobile banking affects the performance of SMEP microfinance institution. This section presents the customer's and the SMEP staff's opinion on and attitude. Evaluating on the contribution of M- Banking Transactions on the performance of SMEP microfinance institution was highly significant in order to highlight the effect of microfinance on the performance on the microfinance intuitions.

Table 4.4 M-banking transaction is welcomed by most of the clients

\begin{tabular}{lcc}
\hline M-banking transactions & Response & Percentage (\%) \\
\hline Remote deposit capture. & 37 & 77 \\
Balance transfers. & 30 & 63 \\
Bill pay. & 29 & 60 \\
Stock trading & 33 & 67 \\
Person to Person payments & 29 & 60 \\
\hline
\end{tabular}

Out of the 48 respondents that were interviewed, 37 (77\%) confirm that they appreciate m-banking because it helps then capture the deposit in remote areas, while $30(63 \%)$ welcomes the concept of mobile banking technology as it helps them in quick balance transfer. Meanwhile, 29(60\%) appreciates m-banking facilities because it helps them in prompt payment of bills and person to person payments. On the other hand, 33 (67\%) likes m-banking because it helps them in stock trading. 


\section{Interactive function and the Performance of Microfinance Institution}

The study wanted to look at how interactive nature of m-banking affects the performance of SMEP microfinance institution. This section presents the customer's and the SMEP staff's opinion on and attitude. Evaluating the interactive nature of m-banking on the performance of SMEP microfinance institution was highly significant in order to highlight the effect of microfinance on the performance on the microfinance intuitions.

\section{M-banking encourages interaction between the client and the microfinance institution}

It was imperative to investigate whether m-banking promotes interaction hence relationship between the MFIs and the client. This was crucial in order to find out how cordial relationship between the MFI and the client is necessary for the institution's performance.

Table 4.5 shows the response

Table 4.5: M-banking encourages interaction between the client and the microfinance institution

\begin{tabular}{lcc}
\hline & Frequency Response & Percentage Response \\
\hline Yes & 40 & 83 \\
No & 6 & 13 \\
I don't know & 2 & 4 \\
\hline Total & $\mathbf{4 8}$ & $\mathbf{1 0 0}$ \\
\hline \hline
\end{tabular}

Source; Research data (2014)

Of the 48 respondents interviewed, 40 (83\%) of respondents confirmed M-banking encourages interaction between the client and the microfinance institution necessary for the bank's performance. However, only $6(13 \%)$ did not agree with this statement, while $2(4 \%)$ could not tell whether there is a relationship between m-banking and interaction between the client and the microfinance institution.

\section{Summary Of Data Analysis}

Data analysis based on the study objectives can be summarized as follows; the first objective was to investigate the effects of Information as a Component of Mobile Banking Service on the Performance of Microfinance Institution. The study sought to investigate how information as a product of mobile banking affects the performance of SMEP microfinance institution. Evaluating the customer's attitude and opinion on the contribution of information on the performance of SMEP microfinance institution was highly significant in order to highlight the effect of microfinance on the performance on the microfinance intuitions. On this regard, the study wanted to find out the opinion and attitudes of the customers regarding the speed and promptness of the information they receive from the financial intuitions through m-banking services. Of the 48 respondents interviewed, $46(97 \%)$ of respondents admitted that ever since the microfinance institution adopted m-banking technology, they have continued to receive the banking information promptly. However, a paltry $2(3 \%)$ could not see the relationship between adoption of mobile banking and the speed they receive the information, claiming that still the speed of conveying information has not improved.

This response concurs with the findings of Laforet and Xiaoyan (2004) in their study of consumers' attitudes towards online and mobile banking in China. According to their report, mobile Banking is a financial transaction conducted by logging on to a bank's website using a cell phone, such as viewing account balances, making transfers between accounts, or paying bills has increased the customer's confidence with the bank given that they receive their banking information promptly through the use of the internet or mobile phone.

It was also significant to investigate effects of prompt information services due to m-banking on the customer base. In this case, the study wanted to investigate whether prompt information services due to $\mathrm{m}$ banking positive effects on the clientele base. Of the 48 respondents interviewed, 40 (83\%) of respondents confirmed that ever since the microfinance institution adopted mobile banking technology, they have witnessed the clientele growth of the microfinance institution. However, only 6(13\%) did not agree with this statement, while $2(4 \%)$ could not tell whether there is a relationship between prompt delivery of banking information and the growth of the customer base.

According to Williams and Torma (2007), m-banking transactions can simultaneously enhance the outreach of financial services, reduce information asymmetries and provide relatively low cost informational and transactional financial products. It therefore has the potential to transform the access to finance for a significant number of people. The next objective was to find out the effects of M- Banking Transactions as a Component of Mobile Banking Service on the Performance of the MFIs. The study sought to examine how mbanking transactions as a product of mobile banking affects the performance of SMEP microfinance institution.

This section presents the customer's and the SMEP staff's opinion on and attitude. Evaluating on the contribution of M- Banking Transactions on the performance of SMEP microfinance institution was highly significant in order to highlight the effect of microfinance on the performance on the microfinance intuitions. 
Out of the 48 respondents that were interviewed, 37 (77\%) confirm that they appreciate m-banking because it helps then capture the deposit in remote areas, while $30(63 \%)$ welcomes the concept of mobile banking technology as it helps them in quick balance transfer. Meanwhile, 29 (60\%) appreciates m-banking facilities because it helps them in prompt payment of bills and person to person payments. On the other hand, 33 (67\%) likes m-banking because it helps them in stock trading.

According to Amin (2007), mobile banking or M-Banking also refers to the provisioning and availability of banking and financial services through mobile technology and the scope of services offered may include facilities to conduct bank and stock market transactions, as well as enabling users to access customized information. Mobile Remittances, Micro-finance and Micro-payments services are likely to fuel the growth of M-banking in the developing countries especially amongst the un-banked segment hence increasing the performance of the microfinance institution. It was also significant to examine how the interactive function of m-banking and the Performance of Microfinance Institution. In this case, the study wanted to look at how interactive nature of $\mathrm{m}$-banking affects the performance of SMEP microfinance institution.

Evaluating the interactive nature of m-banking on the performance of SMEP microfinance institution was highly significant in order to highlight the effect of m-banking on the performance on the microfinance intuitions. Moreover, it was imperative to investigate whether $\mathrm{m}$-banking promotes interaction hence relationship between the MFIs and the client. This was crucial in order to find out how cordial relationship between the MFI and the client is necessary for the institution's performance. Of the 48 respondents interviewed, 40 (83\%) of respondents confirmed M-banking encourages interaction between the client and the microfinance institution necessary for the bank's performance. However, only $6(13 \%)$ did not agree with this statement, while $2(4 \%)$ could not tell whether there is a relationship between m-banking and interaction between the client and the microfinance institution.

Pickens (2009) found in his study that cash transactions, account opening and other transactions can be conducted online. This makes it easy to subscribe and accounts for the high customer concurrence of $91 \%$. Ultimately transformational banking boosts access to formal finance particularly, in rural areas where many poor people live and boosts the interaction between the bank and this group.

\section{Data Interpretation}

The data interpretation is based on the study objectives in accordance with the purpose of the study and according to the first objective, the study sought to investigate how information as a product of mobile banking affects the performance of SMEP microfinance institution. This objective was investigated based on the speed and promptness the customers receive the information when the bank uses m-banking technology. According to the findings, large number of respondents confirms that they receive the banking information promptly as opposed to older days when it could take time to access the information as the system was all manual.

This is justified by the findings of Laforet and Xiaoyan (2004) in their study of consumers' attitudes towards online and mobile banking in China. They found that m-banking technology is widely used as tool for financial transaction by the customers where they log in to a bank's website using a cell phone, such as viewing account balances, making transfers between accounts, or paying bills and this, they report that it has increased the customer's confidence with the bank given that they receive their banking information promptly through the use of the internet or mobile phone.

Assessing the nature of m-banking on the performance of SMEP microfinance institution was very crucial so as to highlight the effects of the use of m-banking on the performance on the microfinance intuitions. This was essential to find out whether m-banking technology promotes and sustain interaction and rapport between the MFI and the customers. According to the findings, majority of the respondents agreed that $\mathrm{m}-$ banking has promoted their level of interaction with the MFI since they access the banking information they need any time without delays. Pickens (2009) similarly found in his study that cash transactions, account opening and other transactions can be conducted online through using mobile phones. This makes it easy and ultimately boosts access to formal finance particularly, in rural areas where many poor people live and the interaction between the bank and this group is also increased.

\section{Limitation Of The Study}

Although the research study was successful, it encountered some challenges which were a major drawback for comprehensively covering the study objectives. Some of these drawbacks include; Language barrier; just like it was anticipated, it was difficult to communicate to all the respondents in the study using the national languages. This is because some of the respondents were illiterate and therefore, only able to speak their mother tongue. This challenge was overcome by getting interpreters in such cases. 


\section{Reference}

[1]. Babbie, E. (2007). The Practice of Social Research. Twelfth Edition.USA: Chapman University.

[2]. Balogun J. (2000). Impact of GSM on Economy and Development. Center for Culture andTechnical Interchange between East and West, Gwalada Abuja.

[3]. BIS (2000); Survey of electronic money developments, May 2000. Switzerland: Bank for Blake, M. (2004).Growing mobile market in Africa. The Electronic Library 22 (4), p.370.Communication in Nigeria: A Breakthrough in Interactional Enhancement or a Drawback? Nordic Journal of African Studies 14(2): 193 - 207 (2005) Thesis. University of Ibadan, Nigeria.

[4]. Bryman, A. (2008). Social Research Methods. Third Edition.New York: OxfordUniversity Press.

[5]. Brynjolfsson, E., \& Hitt, L. (2003). Computing Productivity: Firm-Level Evidence. Review of Economics and Statistics, 85, 793-808.

[6]. Buhalis, D. (2003). eAirlines: strategic and tactical use of ICTs in the airline industry Information and Management, 41, 805-825.

[7]. Cavana, Y. R., Delahaye, L. B., \& Sekaran, U. (2001). Applied business research: qualitative and quantitative methods. Milton, Qld: John Wiley \& Sons.

[8]. Central Bank of Nigeria (2000); CBN Bankers Committee, Report of Sub-committee on Small Scale in Industries.

[9]. Central Bank of Nigeria (2003), Report of the Technical Committee on Electronic Banking.Central Bank of Nigeria (CBN) Report, 2011

[10]. Chang, H.H. and Wong, K.H. (2010) Adoption of E-procurement and Participation of E- marketplace on Firm Performance: Trust as a Moderator, Information \& Management, 47, 5, 262-270.

[11]. Cheng, and Yeung (2006) Adoption of Internet Banking: An Empirical Study in Hong Kong, Decision Support Systems,42, 3, 1558-1572.

[12]. Garbarino, E. and M. Strahilevitz, "Gender differences in the perceived risk of buying online and the effects of receiving a site recommendation," Journal of Business Research, Vol. 57, No. 7: 768-775, 2004.

[13]. Ghauri, P., \& Gronhaug, K. (2010). Research methods in business studies: A Practical guide (4thed). Upper Saddle River, New Jersey: Prentice Hall.

[14]. International Engineering Consortium I.E.C. (2005).Global system for mobile communication (GSM) definition \& overview. Available at: http://www.iec.org/online/tutorials/gsm [accessed on 10 May 2006].

[15]. Joshua, A. J. and M. P. Koshy, "Usage patterns of electronic banking services by urban educated customers: Glimpses from India," Journal of Internet Banking and Commerce, Vol. 16, No. 1: 1-12, 2011. ISSN: 2306-9007 Adewoye (2013) 343

[16]. Kombo, D. K., \&Delno, L. A. T. (2006). Proposal and Thesis Writing: An Introduction. Nairobi: Pauline's publications Africa.

[17]. Lai and Li (2005) Technology Acceptance Model for Internet Banking: An Invariance Analysis, Information \& Management, 42, 2, 373386.

[18]. Lu, J., C. S. Yu, and C. Liu, "Mobile data service demographics in urban China," The Journal of Computer Information Systems, Vol. 50, No. 2: 117-126, 2009.

[19]. Luarn, P. and H. H. Lin, "Toward an understanding of the behavioral intention to use mobile banking," Computers I Human Behavior, Vol. 21: 873-891, 2005

[20]. Lyman, T.R., Pickens M. \& Porteous D. (2008), "Regulating Transformational Branchless Banking: Mobile

[21]. Mas, I. (2008), "Realizing the Potential of Branchless Banking: Challenges Ahead", In: Focus Note 50. Consultancy Group to Assist the Poor (CGAP), Washington, D.C

[22]. Mattila, M. (2003), "Factors affecting the adoption of mobile banking services", Journal of Internet Banking and Commerce, 8 (1), pp101119

[23]. Morna S.Y. Lee, Peter J. Mc Goldrick, Kathleen A. Keeling, Joanne Doherty, (2003) "Using ZMET to explore barriers to the adoption of 3G mobile banking services", International Journal of Retail \& Distribution Management, Vol. 31 Iss: 6, pp.340 - 348)

[24]. Mugenda, O.M., \& Mugenda, A.G. (1999). Research Methods: Quantitative and Qualitative Approaches. Nairobi: African Centre for Technology Studies (ACTS)

[25]. Nigerian Businessinfo.com (2003).Revisiting Nigeriae ${ }^{\text {es }}$ telecommunications industry. Available at: http://www.nigriabusinessinfo.com/telecoms080903.htm Accessed on 12/05/06.

[26]. Oliner, S. D. and D. E. Sichel, 2000, The resurgence of growth in the late 1990s: Is information technology the story? Journal of Economic Perspectives 14, 3-22. Oxley, J. and B. Yeung, 2001, E-commerce Readiness: Institutional Environment and International Competitiveness, Journal of International Business Studies, 32, 705-724.

[27]. Olivier, Henry (2000): "Challenges facing the accountancy profession", European Accounting Review, Volume 9, Issue 4 December 2000, pages $603-624$.

[28]. P. Luarn, H. Lin, (2005)“Toward an understanding of the behavioral intention to use Mobile Banking”, Computers in Human Behavior, vol. 21, 2005, pp. 873-891.

[29]. Parasuraman, A,.Zeithlaml, v. \& berry, L (2002), „Service Quality Delivery through web sites: A critical review of extant knowledge, „Journal of the Academy of marketing Science, fall 2002; vol. 30. No. 4 pp 362-375.

[30]. Parthasarathy, M. and A. Bhattacherjee, 1998, Understanding Post-Adoption Behavior in the Context of Online Services, Information Systems Research 9, 362-379.

[31]. Punch, F.K. (2010). Introduction to Social Research: Quantitative and Qualitative Approaches.Second Edition.New Delhi: Sage Publications Ltd.

[32]. S. Laforet, X. Li,(2005) "Consumers" attitudes towards online and Mobile Banking in China", International Journal of Bank Marketing, vol. 23, no. 5, 2005, pp. 362-380.

[33]. S.J. Barnes, and B. Corbitt, "Mobile Banking: concept and potential", International Journal of Mobile Communications, vol. 1, no.1

[34]. Schurig,(2004) "Assessment of today"s Mobile Banking applications from the view of customer requirements", Proceedings of the 37th Hawaii International Conference on System Sciences, Big Island, Hawaii, January 5-8, 2004.

[35]. Shankar, and D. K. Banwet, "Structural modeling and mapping of m-banking influences in India," Journal of Electronic Commerce Research, Vol. 13, No. 1: 70-87, 2012. Koening-Lewis, N., A. Palmer, and A. Moll, "Predicting young consumers"e take up of mobile banking services," International Journal of Banking Marketing, Vol. 28, No. 5: 410-432, 2010.

[36]. Wojuade, (2006): Stakeholderse Perceptions of the Impact of GSM on Nigeria Rural Economy: Implication for an Emerging Communication Industry, Journal of Information Technology Impact Vol. 7, No. 2.pp. 131 - 144, 2007 ISSN: 2306-9007 Adewoye (2013) 344

[37]. Wolverton, M. L. (2009). Research design, hypothesis testing, and sampling. Appraisal Journal, 77(4), 370-382

[38]. Yang, Z. (2001), „Consumer perceptions of service quality in internet-based electronic commerce ${ }^{\text {ee }}$ Proceedings of the 30th EMAC Conference, 8-11 May, Bergen

[39]. Zhu,et al (2005), Post-Adoption Variations in Usage and Value of E-Business by Organizations: Cross-Country Evidence from the Retail Industry, Information Systems Research 16, 61- 84. 